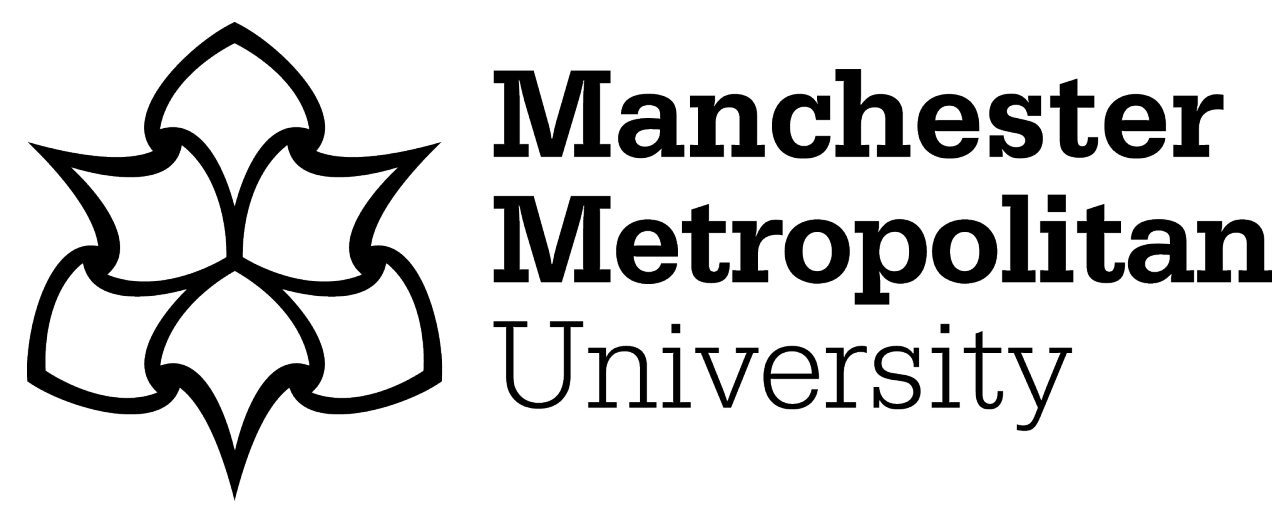

Kalandides, A (2018) Citizen Participation: Towards a Framework for Policy Assessment. Journal of Place Management and Development, 11 (2). pp. 152-164. ISSN 1753-8335

Downloaded from: https://e-space.mmu.ac.uk/620372/

Version: Accepted Version

Publisher: Emerald

DOI: https://doi.org/10.1108/JPMD-02-2018-0017

Please cite the published version 


\section{Citizen participation: towards a framework for policy assessment}

\begin{tabular}{|r|l|}
\hline Journal: & Journal of Place Management and Development \\
\hline Manuscript ID & JPMD-02-2018-0017.R1 \\
\hline Manuscript Type: & Academic Paper \\
\hline Keywords: & participation, policy, Berlin, public sphere, citizenship, civil society \\
\hline \multicolumn{2}{|c}{} \\
\end{tabular}

SCHOLARONE $^{\text {IM }}$

Manuscripts 


\section{Citizen participation: towards a framework for policy assessment}

\section{Introduction}

Citizen participation is of growing interest across several disciplines, albeit with divergent meanings (s. for example Healey, 1997; Hickey and Mohan, 2004a; Cooke and Kothari, 2001; Cornwall and Coelho; 2006; Cornwall, 2008a, 2008b). The task of tracking those meanings becomes more difficult when one considers that other concepts (engagement, involvement, collaborative planning, inclusion) are also used to denote something rather similar. Also, 'participation' has been used with different attributes: "community”, “civic” and "citizen” participation in "planning”, “development”, “urban development”, "governance”, etc. Beside different geographical trajectories in the conceptualization, development, and implementation of participation (revealed through a 'genealogical' and 'critical historical' perspective, as attempted by Huxley, 2013), there is an additional difficulty inasmuch as the term is used both in vernacular and academic language. Finally, there is always an inherent conflict in the way a concept is used in theory creation and policy design (Jessop, 2002).

The above considerations of concepts, attributes, keywords and phrases open a vast semantic field with several possible meanings and connotations. It is not my intention in this paper to present an argument for a 'correct' use of the concept of 'citizen participation', but rather to contribute to conceptual clarity through a reading of its different uses while considering what each variation of the term does. Arnstein's "Ladder of citizen participation" (1969) is often considered a seminal text in the relevant discussion in the US, as is the Skeffington Report of the same year in the UK (s. Huxley, 2013). While the latter approaches participation as a planning procedure, Arnstein, who calls for a 'redistribution of citizen power', demands a more radical approach:

"It is the redistribution of power that enables the have-not citizens, presently excluded from the political and economic processes to be deliberately included in the future. [...] Participation without redistribution of power is an empty and frustrating process for the powerless. It allows [...] only some of the sides to benefit." (Arnstein, 1966:216). 
Arnstein permits us to expand our reading of participation and extend our consideration beyond purely procedural matters towards more basic concepts of power, its (re)distribution and claims to it. It also begs the question of who benefits from participation and in what ways.

The aim of this article is to contribute to the above academic debate on participatory urban development in two ways: firstly, by proposing a methodological framework though which urban policies can be assessed; and secondly through a case study which applies the framework, delivering an analysis of the policy intentions of the current Berlin administration. After this short introduction, the first section of the article introduces the case study, placing it in the political context in Berlin and suggesting an initial reading of the relevant documents that frame policy in participatory urban development today. Section two includes an attempt at disambiguation, a conceptual and an analytical framework, followed by a preliminary assessment of the Berlin participatory policy. The final part of the article draws conclusions and sets a possible future research agenda.

At this point I would like to propose a provisional definition of participation as both a democratic right and a process through which citizens engage in the public sphere to shape policy. Although certainly incomplete, it is useful as a first approach through which relevant passages in official documents can be identified.

A short methodological notice: The way the document proceeds is from an initial description of the case study, to theories that can help understand it and back to the case study, performing the analysis. The consequence of this procedure is that the choice of theories is guided by the case itself. Had we looked at a different example, it may have revealed a different set of useful theoretical tools. In that sense, the theoretical part of the paper, funnelled through the case study, can be both eclectic and incomplete.

\section{The politics of participation in Berlin}

German planning law includes formal participation in urban planning. Failure to comply can lead to an annulment of planning results. Alongside such formalised participation, the State of Berlin has experimented with other forms of citizen 
involvement in urban development since the 1980 s, e.g. the "gentle" urban renewal during the International Building Exhibition (IBA) in 1987 (Bernt, 2003).

Ongoing privatization of state assets after 2000 led to a rekindling of protest movements, some of which led to successful contestation. "Media Spree versenken" (Scharenberg and Bader, 2009) or "100\% Tempelhofer Feld" (Kaschuba and Genz, 2014), both ended in successful local referenda, which not only managed to stop planned developments, but strengthened the movements themselves and confirmed an already existing public consciousness in Berlin, that urban social movements can indeed shift policy making (Novy and Colomb, 2013). In brief, citizen participation as an active claim has a long history in Berlin and is engrained into local politics.

A new coalition government (henceforward "Coalition") between the Social Democrats (SPD), The Greens and The Left was formed as a result of the September 2016 elections in the State of Berlin. The three parties signed an agreement of cooperation for the period 2016-2021, known as the Coalition Agreement (Koalitionsvereinbarung, henceforward "Contract"). One of the provisions in the Contract is for citizen participation as one of the guiding principles of urban development. This document forms the basis for analysis in this paper. Whereas it is too early to assess its results, it is possible to critically consider its intentions.

The foreword to the Contract opens with a series of framing concepts, that act as guiding values behind the document: (1) The Coalition stands for social justice; (2) Governmental policy in Berlin puts people from all social milieus at its core; (3) Berlin respects diversity and all people "independent of ethnic background, religion, skin colour, sexual orientation and identity or gender and age" (Koalitionsvereinbarung 2016:9); (4) Everybody should have the possibility to participate equally in the success of the city; (5) Good work for everybody allows selfdetermined participation in society. Good education is the basis for social participation; (6) Housing is a basic right.

The Contract consists of 5 chapters and participation is present in several sections in more or less explicit ways: Chapter I ("Investing in the city of tomorrow"), first section "Best education opportunities for more participation"; part of the section on urban development, "Urban development in Berlin - intelligent, sustainable and 
participatory”. In chapter III (“A liveable Berlin close to the citizen”) there is a full section on "Civic involvement and participation". Participation is also present in the content, if not in the title, of other sections.

Chapter I ("Investing in the city of tomorrow") begins with a section on education as a condition of participation in society [1]. In this chapter, "supporting democratic understanding” from a young age where young people can experience and test democratic practices is an expressed goal. By strengthening political education and student representation, the Coalition intends to help the creation of a democratic culture at school.

"Affordable housing for everybody" is a further goal in the same chapter, based on the principle of housing as a basic right for all Berliners, a provision already integrated in the constitution of the State of Berlin. It includes the safeguarding of the social and functional urban mix, the protection of tenants from displacement, avoidance of homelessness and social exclusion, investments in affordable housing, participatory planning and active tenant associations. Regarding the latter, state (Berlin)- owned housing companies shall be role-models in applying citizen participation procedures in new construction projects. The coalition explicitly supports tenants' participation in decision-making.

"Urban development in Berlin - intelligent, sustainable and participatory" opens with the goal of "strengthening citizen participation and planning culture" and states the motivation behind it: "urban development is successful when it is designed together with those with stakes in it" (Koalitionsvereinbarung, 2016: 31). The Senate (i.e. the Berlin government) promises to develop guidelines for participation to strengthen it [2]. Procedures shall become lower-threshold, more flexible and more representative. A new online platform (mein.berlin.de) [3] will inform citizens about all development plans, so that citizens can participate. Online participation will be further developed, and contact points for participation will be created, both at a state (Berlin-wide) and municipal (borough) level. The existing event series Stadtforum [4] will continue to inform public debate. Berlin will also examine the possibility of changing the law on planning implementation (AGBauGB) to include more participation in it. Public enterprises shall consider participatory processes in their building plans. Participation appears at every aspect of planning: green planning, new 
neighbourhoods, public transportation, etc. Combating inequality, strengthening social cohesion and civic involvement as well as the creation of integration management for refugees are further goals expressed in this section.

In the section about energy ("Berlin - A pioneer for climate protection and energy transition"), the integration of citizens for the success of energy transition appears in the very first paragraph: new forms of participation, real transparency, active control and financial participation. The communal energy provider shall be largely controlled by the Berlin parliament. A steering committee on energy transition shall be constituted with actors from the environmental, housing and consumer protection associations as well as from businesses, unions and academic institutions.

Social cohesion and proximity to citizens are goals to be found in the section on "Budget and financial policy", together with transparency and the extension of citizen budgets. Regarding the latter, the contract states that an expressed goal of the Coalition is to strengthen participatory democracy. Giving citizens the possibility to co-decide on how to use budgets will strengthen Berlin's political culture.

Chapter II ("Strengthening social cohesion") opens with a section on work. Different lines of exclusion are mentioned, together with goals to overcome them: people with disabilities, the elderly, the poor, and the homeless are explicitly mentioned. In the case of the elderly, the Contract provides for a participatory design of guidelines in relevant policy. In the same section the goal is expressed to strengthen volunteering by opening a dialogue on the Berlin Charta of Civic Involvement, which has been in operation since 2004. A strategy on how to strengthen volunteering networks shall be developed in a participatory method.

A section is dedicated to gender parity ("Half of the power to women") and one to sexual diversity (“Rainbow Capital Berlin"). Instruments such as gender mainstreaming and gender budgeting are discussed, feminism and sex workers are also explicitly mentioned. Civil society and the parliament shall be included in the further development of a gender equality policy. Women's projects as forms of selforganization and spaces of feminist deliberation shall be protected and strengthened. Sexual diversity shall be protected, and LGBTTQ* rights strengthened. 
"Metropole Berlin - open to the world, diverse, just" stresses the need for a law against discrimination, in particular in relation to refugees and migrants and a further development of the law on Participation and Integration [5].

Berlin's policy as a "Cultural and Media Metropolis" is based on the principle that participation in culture is a condition for social participation. Cultural policy shall be based on participation and dialogue with artists. As free and independent media are indispensable for the functioning of democracy, opinion-making and deliberation, the Coalition shall support the independency of media and further develop public media corporations. The coalition shall fight for a free and open internet as the basis of social, economic and democratic participation.

The development of citizenship and suffrage rights is acknowledged in a section on justice ("Berlin Judiciary in an effective state governed by the rule of law"). Here, the Coalition will put forward an initiative to change the German Basic Law, to give voting rights at a state level for EU citizens and, under certain conditions, at a municipality level for third state citizens. The Coalition shall also introduce an antiprivatisation clause in Berlin's constitution, which will make clear that substantial parts of public companies can only be sold if the majority of Berliners agree in a referendum.

"Civic involvement and participation" states the strong relationship between civic involvement, social integration and participation: social businesses, welfare organizations, religious communities, political participation, etc. The Coalition shall strengthen direct democracy and introduce new formats of participation and communication between Senate (government) and citizens. All participation processes shall be found on the new online platform "mein berlin". Citizens will have the possibility to codetermine neighbourhood funds and citizens' budgets.

\section{A methodological framework}

Examining the context where the term 'participation' appears, can add to the clarification of its use. By context I mean both the broader theoretical concepts it fits into, but also all the words that seem to accompany participation: civil society, public sphere, governance, planning, placemaking, civic engagement, etc. 
The concept of civil society seems intrinsically linked to that of participation. Indeed, for many authors, a strong civil society is a precondition for democracy (s. Cohen and Arato, 1996; Putnam, 1993; Tester, 1992; Walzer, 1995). Uses of the term ranges from a synonym for "citizenry" (i.e. a collective noun for citizens); to a Marxist and Gramscian understanding where it is juxtaposed to the political society; an understanding that equates it with a "privately-ordered capitalist economy" (Frazer, 1990:74); and finally, to the 'associational' view, arguably the most common form in use today. The latter can be found in its politicized variant (which includes political party organizations and trade unions) or its more apolitical one, that concentrates on voluntary organisations and NGOs. Civil society may refer to "a third sector of private associations [...] autonomous from both state and economy" that are voluntary and do not work for profit. (Young, 2000:158); or "the nexus of nongovernmental or 'secondary' associations that are neither economic nor administrative" (Frazer, 1990:74). Such a distinction (i.e. of the civil society separate from state and the economy) "helps define [...] the role of civil society in promoting social justice" (Young, 2000:158). A critical approach to the civil society and the public sphere ought to "render visible the ways in which social inequality taints deliberation" and how different publics "are differentially empowered or segmented" and some subordinated to others. (Frazer, 1990:77). A discourse grounded in a homogenous understanding of the "civil society" obfuscates its internal contradictions, as well as the way that power fault lines are drawn and redrawn constantly. This homogenizing discourse then tends to reproduce existing hegemonic relations (Walzer, 1991).

In a different view, a strong 'civil society' is not an alternative to the state, but rather complements it. State and civil society have different functions and operate at different scales (Young, 2000). Civil society can promote social justice as selfdetermination, overcoming domination and the institutional conditions that prevent people "from participation in decisions and processes that determine their actions" (Young, 2000:156). It may however be less effective than the state in promoting social justice as self-development, i.e. in countering oppression and the systematic institutional processes that prevent people from developing skills or freely interacting with others in social life. Parliament which "functions as a public sphere within the state" and whose discourse encompasses both opinion-formation and decisionmaking is a 'strong public' (Frazer, 1990:75). 
Social movements, acting in a space of "noninstitutional politics" (Offe, 1985:826), seek to politicize the institutions of civil society, beyond the "representativebureaucratic political institutions" thereby constituting a civil society not dependent upon regulation, control, and intervention (Offe, 1985:820). They often build upon the Lefebvrian "Right to the City", whereby rights are not there to be taken, but are created through social and political action (Marcuse, 2014; Mayer, 2009).

Citizenship is a recurrent term in the political vocabularies of social movements and has been expanded beyond the acquisition of legal rights, to include concepts of citizens as active social subjects, struggling for the recognition of such rights. (Dagnino, 2011; Vaiou this issue). There is however a reading of citizenship, that moves away from collective rights, where it is understood primarily as the integration of individuals into the market. Both readings rely on a "vibrant and proactive civil society" and use the concept of participation albeit with different meanings (Dagnino, 2011: 419).

Participatory citizenship, directly linked to the struggles of social movements, challenges the definition of what constitutes "the public arena - its participants, its institutions, its processes, its agenda and its scope" (Dagnino, 2007: 419). As "a right to have rights", it can be conceived as "a struggle for the expansion of democracy". It goes beyond the recognition of legal rights and demands a new sociability - a different way of living with each other, a different public sphere in which rights determine the parameters of the negotiation of conflicts. Asserting something as a right (e.g. the right to housing), agency and the capacity to struggle are all projects of participatory citizenship. The direct participation of civil society and social movements in state decisions carries with it the potential of radical transformation (Dagnino, 2007).

The creation of a public sphere is a function of an active civil society, through which it aims "to influence or reform state or corporate politics and practices" (Young, 2000:163). The public sphere is a tool through which organized citizens can limit power and hold powerful actors accountable (Young, 2000:174). It can influence policy (ibid: 177) and can "change society through society", by proposing alternative norms and practices (ibid: 178). 
The existence of a public sphere is often considered a precondition for a functioning democracy, indeed as a 'space' of deliberation and public debate (Habermas, 1965 and 199; Arendt, 1958), where citizens control state and corporate power (Fraser, 1990; Young, 2000). In its Habermasian understanding, there is a basic distinction between the institutions of the state apparatus from public arenas of citizen discourse and association (Habermas, 1965; 1983). "Talk" and "deliberation" are the central features of the public sphere, a space distinct from the state and the "officialeconomy”. There exists however another theorization of public spheres as plural, as spaces where societal groups engage in issues that may contest the hegemony of the bourgeois public sphere - thus producing "subaltern counterpublics" (Fraser, 1990); and there is the viewpoint that connects the two, seeing democratic deliberation functioning in public sphere understood both as singular and plural, whereby the penetrability and exchange between them defines the quality of the democratic process (Young, 2000). It has also been argued that practices of collective action and solidarity can also constitute public spheres, with claims to participation by excluded groups, and thus with a potential to challenge hegemonic power structures (Vaiou and Kalandides, 2017). Public spheres are constituted at "various social geographies of urban space" (Fraser, 1990:69); deliberation takes place beyond the formal spaces of parliament or town hall, they include the street and the square: public space becomes a privileged site of the public sphere (Young, 2000; Vaiou and Kalandides, 2009). Media, as the primary circulators of ideas, plays a central role in the creation of the public sphere. What happens if media are privately owned and the concerns of subordinate groups have no access to them? (Frazer, 1990).

Participation can also be seen as an aspect of urban governance (Jessop, 2002). It then refers to the institutional setting as well as the formal and procedural mechanisms of co-ordination - or more specifically to the part of the decisionmaking process in urban planning (s. Skeffington Report, 1969). This general shift "from government to governance" has often been interpreted as a part of a broader shift towards a more "entrepreneurial" approach to urban space (Harvey, 1989); or it reflects worries that neither "top-down state-planning [n]or market-mediated anarchy" can manage and resolve major new problems that emerge in the "governability of economic, political, and social life" (Jessop, 2002:43), so that citizen participation is seen as a more efficient process in societal coordination. The concept 
of governance is based on the idea that conflicting parties can identify mutually beneficial outcomes and work towards them (Jessop, 2002). It can also be surprisingly blind to structural power inequalities among governance actors and to the fact that conflicts may produce losers and winners (ibid).

Direct citizen participation in terms of practices in central in the concept of "placemaking" (s. Strydom et al. this issue). Here it is citizens in bottom-up practices that make places (understood mostly as a public space of social interaction), as opposed to planning by politicians, urban planners and other experts. Placemaking places citizens in the position of experts and considers methods of participation, where citizens directly transform space through concrete (cultural) practices, moving beyond deliberation or decision-making.

In order to assess participation in the Berlin Contract- and, it is suggested, other similar policy documents - there is first a need to clarify how participation is explicitly or implicitly conceptualized in the document and second, to articulate a possible set of questions relevant to the analysis. I call the former the 'conceptual framework' and the latter the 'analytical framework'.

\section{Conceptual framework}

There have been several attempts at classifying participation: Arnstein's 'ladder' (Arnstein, 1969), Pretty's classification (Pretty, 1995), White's “typology of interests” (White, 1996), up to more evolutionary approaches (Hickey and Mohan, 2004b). Farrington and Bebbington (1993), propose to assess practices of participation along two axes, depth (engaging participants at few or all stages of a given issue) and breadth (involving a narrow or wide range of people). There seems to be a convergence on a basic distinction between participation as an institutional setting versus participation as a right (Corwall 2008b). Distinctions are not mutually exclusive as there is significant overlapping. The above is however a good starting point for an attempt at classification:

(a) Participation as institutional arrangement: Participation can be understood as an element of governance or more specifically as a part of the decision-making process in urban planning. Here, emphasis is placed on institutional frameworks, methods 
and formats, procedures, the spaces and times of participation as well as on its formalization. Participation mostly moves inside institutionally defined limits. (b) Participation as rights: Participation is more than a procedure; it is a right to be claimed by citizens themselves and is thus linked to citizenship. Social movements are then a particular form of participation, where collective action leads to claimmaking. 'The right to the city', in its more radical reading, challenges the status quo, going beyond the given spaces for participation, demanding fundamental political change.

The short review of concepts above suggests that we could add two more approaches to participation which I propose to call participation in the public sphere and participation as practice.

(c) Participation in the public sphere: Being in and constituting the public sphere(s) means to participate. Exclusion from participation can refer to different fields (exclusion from work, public space, the public realm, etc.); it can take place along different fault lines (gender, ethnicity, race, sexuality, etc); or it can be seen negatively in spatial terms, as segregation. "Subaltern counterpublics" can challenge a hegemonic public sphere, claiming not only participation in it, but rather the constitution of another public sphere on their own terms.

(d) Participation as practice: Participation can be something that takes place even in the absence of or even against institutional frameworks. People participate in a more or less explicitly politicised way through their practices - from humble practices of the everyday to political practices of solidarity or engagement. This includes different types of ad-hoc participation, practices of collective action, volunteering work and placemaking.

\section{Analytical framework}

Civil society, the public sphere, social movements, citizenship and placemaking all point toward the question of the subjects of participation (Young, 2000): who are those people who participate in the public sphere? Do they do so collectively or individually? Are they represented, or do they need to find their own voice? (Cornwall, 2008a). The actual locus of participation is crucial to the possibility to speak out: There are spaces where people speak out and others, which are intimidating or even actively exclusive (Cornwall, 2008a). Under what circumstances 
is the public sphere accessible? Different resources (whether it's time, education, language, etc.) will influence the way people can access the spaces of deliberation (Young, 2000). Equally important as the actors in participatory processes, is the question of who is excluded from participation, either out of choice or because of the institutional setting where it takes place (Cornwall, 2008a). Inclusion and exclusion in participation could be related to what people participate in, the issue and the stage of the process in question, raising questions of place and scale. Furthermore, the motivations of those who adopt the approach - manipulation, co-optation, reducing costs, etc. - matter to our conceptualization and the outcomes of participation (Pretty 1995). Finally, whether citizens and organizations of the civil society participate through invitation or whether they claim that right for themselves, is an important distinction (Cornwall, 2008a).

I propose to use a spatial lens to systematically analyse participation, with a focus on two basic spatial categories, place and scale. Place here is conceptualized both as "formed out of the particular set of social relations which interact at a particular location" and as having the potential to generate new social relations (Massey, 1994: 168). The questions will then need to be on the one hand about the location of interaction and about the social relations that interact on the other: the actors involved, their power relations, their motivations, their history, their ideology, their institutional embeddedness, etc. Such an analysis is also spatial in the sense that it asks the question of the scale of participation - understood as a social construct of interconnections between places (Marston, 2000).

An analytical tool that assesses participation may need to ascertain the following: (a) Subject: Who is meant to participate, who really participates as well as who is excluded from participation.

(b) Intentionality: Why do power-holders yield part of their power? Also, what are the motivations of those who participate?

(c) Object: What is the participatory process about? Is it about a project (i.e. an urban renewal decision) or does it involve broader political issues (i.e. privatization of stateowned facilities)?

(d) Scale: The issue at stake can be local, at a neighbourhood level, it can pertain to a city-wide decision or can involve a national or even supranational matter. It is also about the scale of the polity and of citizenship rights. 
(e) Form: How participation takes place matters. What is the institutional setting? What methods and formats are used? How is participation designed, organized and implemented?

(f) Locus: What is the actual physical spatial setting of participation? Where does participation take place?

(g) History: Where does participatory culture come from? Political relations are embedded in places through a historical process, whereby conflicts, compromises and institutionalization co-develop over time, creating a political culture that encompasses both state institutions and citizens.

(h) Interconnections: How are subjects, objects, ideas, institutions, etc. interconnected across places?

\section{Assessing policy intentions on participation in Berlin}

The two frameworks provide a methodological tool to consider (a) the ways in which participation has been conceptualized in the Berlin Contract and (b) the specific questions that need to be asked to perform its assessment. By applying them on a text analysis of the Berlin Contract we get the tables below:

Table 1: Applying the conceptual framework to the Berlin Contract

\begin{tabular}{|l|l|}
\hline $\begin{array}{l}\text { Conceptualisation of } \\
\text { Participation }\end{array}$ & Participation in the Berlin Coalition Contract \\
\hline Participation as an & $\begin{array}{l}\text { Planning administration currently preparing } \\
\text { guidelines on participation; participatory planning; } \\
\text { Participatory budgeting; participatory neighbourhood } \\
\text { funds; State-owned housing companies preparing a } \\
\text { handbook on participation; online platforms; } \\
\text { Stadtforum; commissioners; points of contact; low } \\
\text { threshold; more flexible; more representative; } \\
\text { transparency; gender mainstreaming }\end{array}$ \\
\hline Participation as rights & $\begin{array}{l}\text { Housing as a social right; right to (political) } \\
\text { education; right to work; } \\
\text { Change in suffrage rights for non-German citizens; } \\
\text { Direct and representative democracy }\end{array}$ \\
\hline Participation in the public & Social justice; Anti-discrimination; gender parity; \\
\hline
\end{tabular}




\begin{tabular}{|l|l|}
\hline sphere & $\begin{array}{l}\text { sexual diversity; access for people with disabilities; } \\
\text { inclusion of refugees; anti-austerity; role of media and } \\
\text { internet; “combatting inequality"; "promoting social } \\
\text { cohesion"; role of parliament }\end{array}$ \\
\hline Participation as practices & Volunteering; civic involvement \\
\hline
\end{tabular}

Table 2: Applying the analytical framework to the Berlin Contract

\begin{tabular}{|l|l|}
\hline Analytical tools & Presence in the Berlin Coalition Contract \\
\hline Subjects & $\begin{array}{l}\text { The Berlin Senate; all state-affiliated institutions; } \\
\text { tenants; citizens; organizations of civil society; artists; } \\
\text { non-German citizens; migrants and refugees }\end{array}$ \\
\hline Intentionality & Efficiency \\
\hline Object & $\begin{array}{l}\text { Cultural policy; housing; budgeting; neighbourhood } \\
\text { funds; privatization; green planning; new } \\
\text { neighbourhoods; public transportation }\end{array}$ \\
\hline Scale & $\begin{array}{l}\text { Housing estate; neighbourhood; borough, city-wide; } \\
\text { national }\end{array}$ \\
\hline Form & Guidelines and guidebooks under preparation \\
\hline Locus & $\begin{array}{l}\text { Not specified; Locational plurality; in and out of } \\
\text { formalized spaces }\end{array}$ \\
\hline History & Tradition of social movements; direct democracy \\
\hline Interconnections & $\begin{array}{l}\text { Berlin's responsibility to the world; policy examples } \\
\text { from other cities }\end{array}$ \\
\hline
\end{tabular}

\section{Conclusions and a possible research agenda}

Participation is present throughout the Contract in surprising frequency. Whilst never explicitly clarified as a term, the analysis performed in this paper shows that the focus lies mostly on the institutional framework. Participation as rights and participation in the public sphere are mostly underlying principles, that however permeate the whole document and are repeated regularly. Participation as practice remains weak, as there is no mention of how the Senate will deal with noninstitutional or even anti-institutional forms of participation such as social movements. 
In the Contract participation takes place in different public spheres - housing, cultural policy, urban planning, privatization policy - and at different scales - the housing estate, the neighbourhood, the borough, the state. But it even considers Berlin's responsibility beyond its borders, in Europe and internationally. This is a geographical responsibility that, as stated in the Contract, stems both from Berlin's (and Germany's) past and from its current hegemonic position in a globalized world.

Social justice, equality, anti-discrimination and social cohesion as values behind the Contract, are meant to allow all citizens to participate equally in the public sphere. Underprivileged groups are explicitly mentioned several times: the poor, women, LGBQT, Roma, migrants and refugees. Austerity as an exclusionary ideology is clearly rejected. The document refers to several power fault lines - class, gender, sexuality and ethnic origin. Whereas participation is not directly present as a right in itself, suffrage rights as well as the rights to housing, education and work are explicitly or implicitly addressed. The Contract considers the extension of voting rights to European citizens and non-European migrants at different polity scales. It also addresses the relationship between direct and representative democracy. Participation is seen as necessary for the success of urban development and institutional transformation is needed to accommodate it: possible change of law, development of both online and offline procedures as well as structures such as participation commissioners and points of contact in the borough. Participation is anchored in institutions and thus the appropriate institutional setting for it is considered: guidelines for the work of government and for state-owned housing companies. A working group for the design of these new citizen participation guidelines has been installed and is expected to deliver results by the end of 2018 . This is probably why practices of participation are only marginally present in the document, with mentions of volunteering and civic engagement at the centre of it.

At this point it is only possible to assess the Contract by identifying the principles upon which it is based and the aspects of participation that are included as well as those that are not. In the document, focus is placed mostly on the institutional framework in a wide range of areas: participatory budgeting, neighbourhood funds, housing, cultural policy, etc. Whereas the former is to be expected from a policy paper (whose main function is to set institutional frameworks), the latter is both a strength and a potential risk: it is a strength because a culture of participation, as shown 
above, needs different public spheres for different publics; it is also a potential risk because it demands a complete overhauling of processes in many areas simultaneously. Participation, taken seriously, means giving up power. Here, we should expect to see backlash, even from inside the administration.

More broadly however, the Contract opens up the potential for a radical reconsideration of participation as a citizenship right, based on the principles of inclusion, social justice, equality, right to housing, right to education, right to work, etc. By proclaiming to put an end to austerity and raising the threshold for privatizations it also makes a political claim against neo-liberal economic policies, as profoundly exclusionary and thus, inherently anti-participatory.

It must be stressed here that the document is not an exact blueprint for the government's work for the next years, as it is not detailed enough for it. It does however state its political intentions and will need to be assessed on implementation and results. Research that assesses implementation alongside the mere intentions of participatory policy will have to go beyond values, principles and institutional arrangements. It will have to look on the one hand at how participation has been ingrained into Berlin society through a combination of strong social movements, institutional adaptation, key actors, etc. On the other hand, it will need to delve into the 'nitty-gritty' and the everyday: examine the people who participate (and those who do not), their concerns and their motivations and analyse the places and the scales where participation takes place. The analytical framework may be a useful tool in this endeavour, but this needs to be shown in further research practice. And finally, comparative work, between Berlin and other cities, may reveal place-specific particularities that define not only the width, depth and form, but also the outcomes of participation.

\section{Endnotes}

[1] The German language contains different words for participation, which do not necessarily overlap with their English equivalent: 'Teilhabe', 'Teilnahme', 'Beteiligung', 'Partizipation', 'Engagement'.

[2] The guidelines were under development as this article was being written. http://www.stadtentwicklung.berlin.de/planen/leitlinienbuergerbeteiligung/index.shtml 
[3] Already functioning at the time this article was being written.

[4] Stadtforum is a series of public events on urban development organized by the Berlin planning department, which has taken place in irregular intervals since 1991. It consists of presentations and debates between members of the administration, experts and citizens.

[5] The law regulating integration and participation (PartIntG) in Berlin went through parliament in 2010. Its goal is to allow persons with a migration background to participate equally in social life.

\section{Participation References}

Arendt, H. (1958), The Human Condition, University of Chicago Press, Chicago. Arnstein, S. R. (1969), "A ladder of citizen participation”, Journal of the American Institute of planners, Vol. 35 No. 4, pp. 216-224.

Bernt, M. (2003), Rübergeklappt: die ,behutsame Stadterneuerung 'im Berlin der 9oer Jahre, Schelzky \& Jeep, Berlin.

Cohen, J. L. and Arato, A. (1994), Civil society and political theory, MIT press, Boston, MA.

Cooke, B. and Kothari, U. (Eds.) (2001), Participation: The new tyranny?, Zed books, London and New York.

Cornwall, A. (2008a), "Unpacking 'Participation': models, meanings and practices”, Community Development Journal, Vol. 43 No. 3, pp. 269-283.

Cornwall, A. (2008b), The Participation Reader, Zed books, London and New York.

Cornwall, A. and Coelho, V. S. (Eds.) (2007), Spaces for change?: the politics of citizen participation in new democratic arenas, Zed Books, London and New York.

Dagnino, E. (2011), “Citizenship: a perverse confluence”, in Cornwal, A. (Ed.), The Participation Reader, Zed Books, London, pp. 418-427.

Farrington, J. and Bebbington, A. with Wellard, K. and Lewis, D. J. (1993), Reluctant Partners: Non-governmental Organisations, the State and Sustainable Agricultural Development, Routledge, London and New York.

Fraser, N. (1990), "Rethinking the public sphere: A contribution to the critique of actually existing democracy", Social text, Vol. 25/26, pp. 56-80.

Kaschuba, W. and Genz, C. (Eds.) (2014), Tempelhof. Das Feld. Die Stadt als Aktionsraum, Humboldt-Universität Berlin, Berlin. 
Koalitionsvereinbarung zwischen Sozialdemokratische Partei Deutschlands (SPD), Landesverband Berlin und DIE LINKE, Landesverband Berlin und BÜNDNIS 90/DIE GRÜNEN Landesverband Berlin für die Legislaturperiode 2016-2021, (2016), available at https://www.berlin.de/rbmskzl/regierenderbuergermeister/senat/koalitionsvereinbarung/ (accessed 2 September 2017) Habermas, J. (1965), Strukturwandel der Öffentlichkeit: Untersuchungen zu einer Kategorie der bürgerlichen Gesellschaft, Luchterhand, Munich.

Habermas, J. (1996), Between facts and norms: Contributions to a discourse theory of law and democracy, MIT Press, Boston, MA.

Harvey, D. (1989), "From managerialism to entrepreneurialism: the transformation in urban governance in late capitalism”, Geografiska Annaler: Series B, Human Geography, Vol. 71 No 1, pp. 3-17.

Healey, P. (1997), Collaborative planning: Shaping places in fragmented societies, Macmillan Press, Basingstoke.

Hickey, S. and Mohan, G. (Eds.) (2004a), Participation. From tyranny to transformation? Exploring new approaches to participation in development, Zed Books, London and New York.

Hickey, S. and Mohan, G. (2004b), "Towards participation as transformation: critical themes and challenges", in Hickey, S. and Mohan, G. (Eds.), Participation-from tyranny to transformation? Exploring new approaches to participation in development, Zed books, London and New York, pp. 3-24.

Huxley, M. (2013), “Historicizing planning, problematizing participation”, International Journal of Urban and Regional Research, Vol. 37 No. 5, pp. 1527-1541.

Jessop, B. (2002), "Governance and Meta-governance in the Face of Complexity: On the Roles of Requisite, Reflexive Observation and Romantic Irony in Participatory Governance", in Heinelt, H., Getimis, P., Kafkalas, G., Smith, R., and Swyngedouw, E. (Eds.), Participatory Governance in multi-level context, Leske+ Budrich, Opladen, pp. 33-58.

Marcuse, P. (2014), "Reading the right to the city", City, Vol. 18 No. 1, pp. 4-9.

Marston, S. A. (2000), "The social construction of scale", Progress in Human Geography, Vol. 24 No. 2, pp. 219-242.

Massey, D. (1994), “A place called home”, in Massey. D. (Ed.), Space, Place and Gender, University of Minnesota Press, Minneapolis, pp. 157-173. 
Mayer, M. (2009), "The 'Right to the City' in the context of shifting mottos of urban social movements", City, Vol. 13 Nos. 2-3, pp. 362-374.

Novy, J. and Colomb, C. (2013), "Struggling for the right to the (creative) city in Berlin and Hamburg: new urban social movements, new 'spaces of hope?", International Journal of Urban and Regional Research, Vol. 37, No. 5, pp. 1816-1838.

Offe, C. (1985), "New social movements: challenging the boundaries of institutional politics", Social research, Vol. 52 No. 4, pp. 817-868.

Pretty, J. N. (1995), “Participatory learning for sustainable agriculture”, World development, Vol. 23 No. 8, pp. 1247-1263.

Putnam, R. D. (1993), Making democracy work: Civic traditions in modern Italy, Princeton university press, Princeton.

Scharenberg, A. and Bader, I. (2009), "Berlin's waterfront site struggle", City, Vol. 13, Nos. 2-3, pp. 325-335.

Skeffington Report (1969), People and planning: report of the Committee on public participation in planning, HMSO, London.

Tester, K. (1992), Civil Society, Routledge, London and New York.

Vaiou, D. and Kalandides, A. (2009), "Cities of 'others': public space and everyday practices”, Geographica Helvetica, Vol. 64 No. 1, pp. 11-20.

Vaiou, D. and Kalandides, A. (2017), "Practices of solidarity in Athens: reconfigurations of public space and urban citizenship", Citizenship Studies, Vol. 21 No. 4, pp. 440-454.

Walzer, M. (1991), "The civil society argument”, Statsvetenskaplig tidskrift, Vol. 94, No. 1, pp. 1-11.

Walzer, M. (1995), “The Idea of Civil Society”, in Walzer, M. (Ed.), Toward a Global Civil Society, Berghahn Books, Providence, RI.

White, S. C. (1996), "Depoliticising development: the uses and abuses of participation", Development in practice, Vol. 6 No. 1, pp. 6-15.

Young, M. I. (2000), Inclusion and democracy, Oxford University Press, Oxford. 